\title{
Physical and Mechanical Characteristics of Rubber-Bitumen Compounds
}

\author{
Ye. Tileuberdi ${ }^{1,2}$, Ye.K. Ongarbaev ${ }^{1,2, *}$, Z.A. Mansurov ${ }^{1,2}$, B.K. Tuleutaev ${ }^{2}$, E.A. Akkazyn ${ }^{1}$ \\ ${ }^{1}$ Al-Farabi Kazakh National University, 71 al-Farabi av., 050039, Almaty, Kazakhstan \\ ${ }^{2}$ Institute of Combustion Problems, 172 Bogenbai Batyr St., 050012, Almaty, Kazakhstan \\ *Corresponding Author: Erdos.ongarbaev@kaznu.kz
}

Copyright @ 2013 Horizon Research Publishing All rights reserved.

\begin{abstract}
In the paper physical and mechanical characteristics of Rubber-Bitumen Compounds (RBC) on based rubber crumb (RC) from worn tires were investigated. At experiment the standard petroleum bitumen BND 60/90 modified with rubber crumb. The spent engine oil was used as additional modifying agent. Images of Scaning Electron Microscopy (SEM) showed that the RC is very low pores heterogeneous material. Physical and mechanical characteristics of rubber modified bitumen with engine oil $(\mathrm{R}: \mathrm{O}=1: 1$ and $\mathrm{R}: \mathrm{O}=3: 2$ ) corresponds to grade of paving rubber-bitumen compounds RBC 60/90, RBC 90/130 and RBC 130/200.
\end{abstract}

Keywords Bitumen, Tire, Rubber Crumb, Rubber-Bitumen Compounds, Penetration, Softening Point, Penetration Index

\section{Introduction}

Well known, petroleum products play an important role in economic development of any nation. Including the bitumen industry takes $2.6 \%$ on refining. Bitumen is a mixture of organic liquids that is viscous, black and sticky. It is a complex mixture of high boiling point range of compounds and molecules with a relatively low hydrogen-to-carbon ratio. In the United States the terms asphalt and bitumen are synonymous, while in other areas, e.g. in Europe and Asia, both terms have different meanings [1-4].

Petroleum bitumen widely used in many industries, including road building constructions. Main problem with road building is the poor quality of bitumens used in asphalt-concrete pavements. One of the ways to improve the quality of the binders is their modification with polymers and rubber crumb $[5,6]$. The utilization of spent rubber materials, for example, automobile tires, is currently one of the most important environmental problems on a global scale because of the rapid growth of the automobile industry [7, 8].

Crumb rubber is a term usually applied to recycled rubber from automotive and truck scrap tires. During the recycling process steel and fluff is removed leaving tire rubber with a granular consistency. Worn or spent tires are valuable secondary raw materials containing $65-70 \%$ rubber, $15-25 \%$ technical-grade carbon, and 10-15\% high-quality metal [8, 9].

Researchers have been offered variety ways of recycling and utilization of rubber crumb from worn tires. A well known method is to burn the rubber waste to produce energy while producing cement [10] and $\mathrm{RC}$ is often used in astroturf as cushioning, where it is sometimes referred to as astro-dirt. RC was used to remove ethylbenzene, toluene and xylene from aqueous solutions at room temperature [11]. Rubber crumb also goes into the manufacturing of several auto parts and manufacturing new tires. A revolutionary nanotechnology process developed by the British group Dena Technology is gearing up worldwide to produce high quality building material as wood-replacement products from used tires. Also uses to paper-replacement materials are investigating [12]. Cut tires are used for the manufacture of drainage tubes, tapes for the protection of cables and pipelines, and soundproof walls along highways and for the protection of downslopes from erosion; Thermal methods for the secondary use of scrap tires are known, in particular, the combustion of tires to generate energy and pyrolysis under conditions of relatively low temperatures to produce light distillate, solid fuel, and metal. In addition, the following technologies are available: the processing of tires to obtain rubber crumbs and powders for the manufacture of polymer mixtures and construction materials and the production of reclaim for the manufacture of rubber mixtures and asphalt-rubber compositions for insulating and roofing materials $[13,14]$.

In the paper [15] reported that the blending time and temperature required to interact the crumb rubber with an asphalt binder is dependent on many factors including the chemistry of the asphalt binder and the crumb rubber as well as the particle size and texture of the crumb rubber and the amount of the crumb rubber. Crumb rubber modified bitumen can improve the heat-resistance, the crack-resistance at low temperature and the durability of bitumen. Asphalt concrete prepared with Rubber-Bitumen 
Compounds exhibits high performance, enhanced wear and heat resistance, and resistance to aging. As a result, the pavement quality grows, and its service life becomes a factor of 1.5 - 2 longer [5, 16-19].

R.Z. Shakhnazarli et. al [20] examined the properties of bitumen compounds prepared with secondary polyethylene, polyamide fiber waster and $\mathrm{CR}$ as filler. The complex modifier of asphalt concrete "KMA" [21] and "UNIREM" [22] were found. In our work, aim of improving the physical and mechanical characteristics of rubber modified bitumen were examined spent engine oil as additional modifying agent.

At experiment RBC samples were prepared with rubber crumb and with rubber-oil mixture. RBC was produced in the laboratory using four percentages of RC $(3 ; 5 ; 7 ; 10 \%$ by compound weight). Rubber-oil mixtures were prepared by mixing spent engine oil into rubber crumb with a ratio at 5:6, $1: 1$ and $3: 2$. After a day it used for preparing rubber-bitumen compounds. Bitumen samples were heated at $160-170{ }^{\circ} \mathrm{C}$ and variety content of rubber-oil mixtures $(10 ; 15 ; 20 ; 25$ wt.\%) were added in bitumen. The compound were stirred for 5 minutes at $165-180{ }^{\circ} \mathrm{C}$.

\section{Experimental Materials and Methods}

\subsection{Materials}

At work were used standard paving bitumen BND 60/90 (from Ltd. «Asphaltobeton-1» in Almaty, Kazakhstan); Rubber crumb from spent tires (from Kazakhstan Rubber Recycling LLP (in Astana, Kazakhstan)) which have two different particle sizes: one type of the rubber crumb is activated, particle size less than $0.6 \mathrm{~mm}$. The other one type is no activated, which particle size between $0.6 \mathrm{~mm}$ and $1 \mathrm{~mm}$; Spent engine oil from Car service in Almaty city.

\subsection{Physical and Mechanical Testing Methods}

The properties of bitumen were described by physical tests. Usually, consistency or some combination of consistency with other basic properties is measured. Testing and the control of properties through specifications are important in any discourse on bitumen $[3,4,19]$. The most commonly used standardized tests were covered in this paper.

Penetration involves the determination of the extent to which a standard needle penetrates a properly prepared sample of bitumen under specified conditions of temperature, load, and time. The unit of penetration is $0.1 \mathrm{~mm}$, which is generally omitted in favor of reporting just the measured number. It was determined by a apparatus Penetrometer PNB-03 (Figure 1) in accordance with standard 11501-78. For the analyses the bitumen sample cup was placed in a water bath at a temperature of $25{ }^{\circ} \mathrm{C}$ for 1 hour and determined by a standard needle penetration depth when the load of $100 \mathrm{~g}$ for $5 \mathrm{sec}$. At standard BND 60/90 means a standard paving grade bitumen with a penetration range between 61 and $900.1 \mathrm{~mm}$.

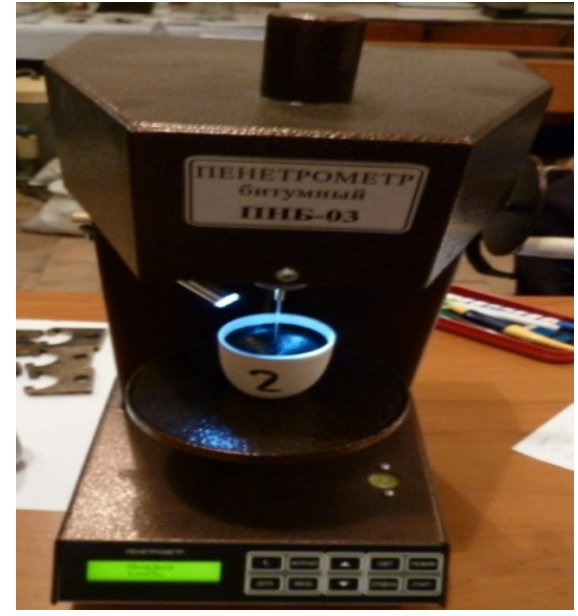

Figure 1. Apparatus "Penetrometer"

Softening temperature - the temperature at which the bitumen of a relatively solid state into the liquid state. The softening point was determined by the method of "ring and ball" according to standard 11506-73. It is a measure of the temperature at which a steel ball passes through a disk of the sample and falls a distance of $25.0 \mathrm{~mm}$ when the specimen, ball, and bath of distilled water were heated on a hot plate at a rate of $5^{\circ} \mathrm{C}$ per minute.

The penetration index characterizes the degree of penetration of colloidal bitumen or rejection of his status from a purely viscous. It is determined by the following empirical formula:

$$
\mathrm{PI}=\frac{30}{1+50 \mathrm{~A}}-10
$$

Where,

$$
\mathrm{A}=\frac{2.9031-\log \mathrm{P}}{\mathrm{SP}-25}
$$

where PI - penetration index, P - penetration at $25^{\circ} \mathrm{C}, 0.1$ $\mathrm{mm}, \mathrm{SP}$ - softening point, ${ }^{\circ} \mathrm{C}$.

The Ductility test gives a measure of adhesive property of bitumen and its ability to stretch. Tensile properties were determined at apparatus Ductilometer CDB-974N (Figure 2) according to standard 11505-75. Ductility of a bituminous material is a measure of the distance in centimeters that it elongates before breaking when the two ends of a briquet specimen are pulled apart at a specified rate and temperature. Water bath was maintained within $0{ }^{\circ} \mathrm{C}$ or $25 \pm 0.1{ }^{\circ} \mathrm{C}$ of the specified test temperature.

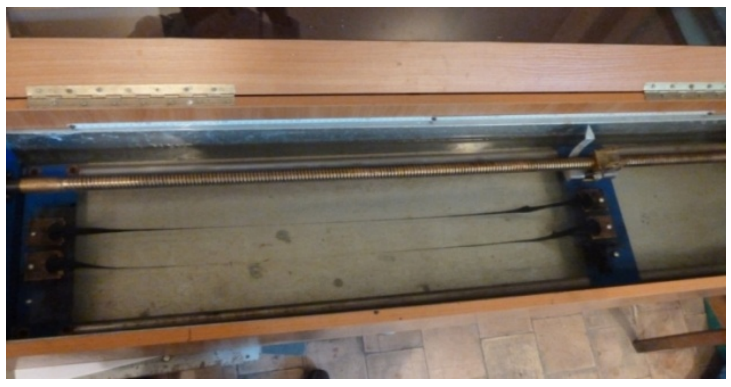

Figure 2. Apparatus "Ductilometer" 


\section{Results and Discussion}

\subsection{Characteristics of Base Bitumen}

Physical and mechanical characteristics of petroleum bitumen BND 60/90 were determined according to standard 22245-90. It is presenting in table 1 . The standard bitumen BND 60/90 have been using on the road construction in Almaty city.

\subsection{SEM Analyses of Rubber Crumb}

The microstructures and microanalysis of rubber crumb were investigated with a Scaning Electron Microscopy (SEM) (Quanta 3D 200i) at an accelerated voltage of $20 \mathrm{kV}$ and pressure at $0.003 \mathrm{~Pa}$. Prepared by National Nanotechnological Laboratory Open Type of Kazakh National University. SEM images (figure 3) showed that the crumb rubber has variety of morphological structures. It was determined, $\mathrm{RC}$ is very low pores heterogeneous material.

Table 1. Characteristics of base bitumen

\begin{tabular}{|c|c|c|}
\hline Characteristics & Results & Units \\
\hline Penetration, at $25^{\circ} \mathrm{C}$ & 78 & $0.1 \mathrm{~mm}$ \\
\hline Penetration, at $0{ }^{\circ} \mathrm{C}$ & 17 & $0.1 \mathrm{~mm}$ \\
\hline Softening point & 47 & ${ }^{\circ} \mathrm{C}$ \\
\hline Ductility, at $25^{\circ} \mathrm{C}$ & 96 & $\mathrm{~cm}$ \\
\hline Penetration index & -0.9 & - \\
\hline Changing SP after heating & 4 & ${ }^{\circ} \mathrm{C}$ \\
\hline
\end{tabular}

\subsection{Activated Rubber Crumb Modified Bitumen}

At first we tested only rubber crumb modified bitumen, which was heated at $160 \pm 5^{\circ} \mathrm{C}$ and 3-10 weight percentage of activated crumb rubber were added in to bitumen. It was prepared by stirring for $5 \mathrm{~min}$ at $170-180^{\circ} \mathrm{C}$. But, results of analyses showed that the samples on the physical and mechanical characteristics were poor indicator, because of lower extensibility. Ductility of rubber modified products was between $7 \mathrm{~cm}$ and $11 \mathrm{~cm}$. In fact, all of the samples were close to standard or mismatch standard requirements of the rubber-bitumen compounds.

The dispersion degree and the swelling capacity of crumb rubber in the bitumen have an important effect on improving properties of bitumen. The swelling of crumb rubber in bitumen is the process that light components in bitumen, such as saturated component, aromatic component, permeate into the crumb rubber. Obviously, the swelling can promote the formation of the elastic network of crumb rubber modified bitumen. So the better the swelling of bitumen to crumb rubber, the better the properties of crumb rubber modified bitumen [6, 17-18].

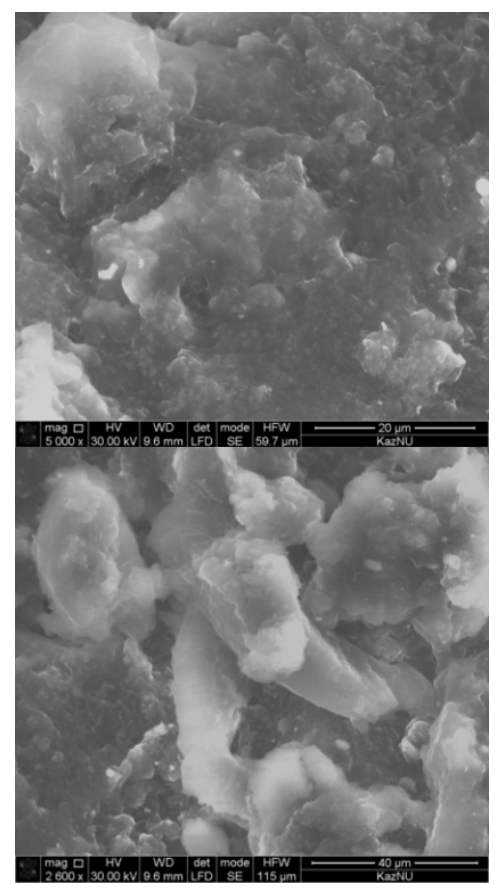

Figure 3. SEM images of rubber crumb

Table 2. Physical and mechanical characteristics of rubber-bitumen compounds with activated rubber crumb

\begin{tabular}{|c|c|c|c|c|c|c|}
\hline \multirow{2}{*}{ Names of indicators } & \multirow{2}{*}{ Rubber-oil ratio } & \multicolumn{4}{|c|}{ Rubber-oil percentage in bitumen } & \multirow{2}{*}{ Methods of testing } \\
\hline & & $10 \mathrm{wt} \%$ & $15 \mathrm{wt} \%$ & $20 \mathrm{wt} \%$ & $25 \mathrm{wt} \%$ & \\
\hline \multirow{2}{*}{$\begin{array}{c}\text { Penetration at } 25^{\circ} \mathrm{C}, \\
0.1 \mathrm{~mm}\end{array}$} & $\mathrm{R}: \mathrm{O}=1: 1$ & 90 & 127 & 126 & 170 & \multirow{2}{*}{$\begin{array}{c}\text { According to standard } \\
11501\end{array}$} \\
\hline & $\mathrm{R}: \mathrm{O}=3: 2$ & 75 & 130 & 109 & 150 & \\
\hline \multirow{2}{*}{ Softening point, ${ }^{\circ} \mathrm{C}$} & $\mathrm{R}: \mathrm{O}=1: 1$ & 51 & 46 & 50 & 48 & \multirow{2}{*}{$\begin{array}{c}\text { According to standard } \\
11506\end{array}$} \\
\hline & $\mathrm{R}: \mathrm{O}=3: 2$ & 58 & 47 & 55 & 46 & \\
\hline \multirow{2}{*}{ Ductility at $25^{\circ} \mathrm{C}, \mathrm{cm}$} & $\mathrm{R}: \mathrm{O}=1: 1$ & 25 & 19 & 26,5 & 22 & \multirow{2}{*}{$\begin{array}{c}\text { According to standard } \\
11505\end{array}$} \\
\hline & $\mathrm{R}: \mathrm{O}=3: 2$ & 19 & 31 & 17 & 25 & \\
\hline \multirow{2}{*}{ Penetration index } & $\mathrm{R}: \mathrm{O}=1: 1$ & 0.6 & 0.3 & 1.5 & 2.2 & \multirow{2}{*}{ By empirical formula } \\
\hline & $\mathrm{R}: \mathrm{O}=3: 2$ & 1.7 & 0.7 & 2.2 & 0.9 & \\
\hline \multirow{2}{*}{$\begin{array}{c}\text { Changing of SP after } \\
\text { heated, }{ }^{\circ} \mathrm{C}\end{array}$} & $\mathrm{R}: \mathrm{O}=1: 1$ & 5 & 5 & 5 & 5 & \multirow{2}{*}{$\begin{array}{c}\text { According to standard } \\
18180 \\
\end{array}$} \\
\hline & $\mathrm{R}: \mathrm{O}=3: 2$ & 4 & 5 & 5 & 6 & \\
\hline \multirow{2}{*}{ Standard accordance } & $\mathrm{R}: \mathrm{O}=1: 1$ & - & - & RBC 90/130 & RBC 130/200 & \multirow{2}{*}{$\begin{array}{l}\text { According to R RK } \\
218-76-2008\end{array}$} \\
\hline & $\mathrm{R}: \mathrm{O}=3: 2$ & RBC 60/90 & - & RBC 90/130 & RBC 130/200 & \\
\hline
\end{tabular}


Table 3. Physical and mechanical characteristics of rubber-bitumen compounds with no activated rubber crumb

\begin{tabular}{|c|c|c|c|c|c|c|}
\hline \multirow{2}{*}{ Names of indicators } & \multirow{2}{*}{ Rubber-oil ratio } & \multicolumn{4}{|c|}{ Rubber-oil percentage in bitumen } & \multirow{2}{*}{ Method of testing } \\
\hline & & $10 \mathrm{wt} \%$ & $15 \mathrm{wt} \%$ & $20 \mathrm{wt} \%$ & $25 \mathrm{wt} \%$ & \\
\hline \multirow{2}{*}{$\begin{array}{c}\text { Penetration at } 25^{\circ} \mathrm{C} \\
0.1 \mathrm{~mm}\end{array}$} & $\mathrm{R}: \mathrm{O}=1: 1$ & 67 & 71 & 90 & 91 & \multirow{2}{*}{$\begin{array}{c}\text { According to standard } \\
11501\end{array}$} \\
\hline & $\mathrm{R}: \mathrm{O}=3: 2$ & 87 & 160 & 195 & 108 & \\
\hline \multirow{2}{*}{ Softening point, ${ }^{\circ} \mathrm{C}$} & $\mathrm{R}: \mathrm{O}=1: 1$ & 50 & 59 & 51 & 58 & \multirow{2}{*}{$\begin{array}{c}\text { According to standard } \\
11506\end{array}$} \\
\hline & $\mathrm{R}: \mathrm{O}=3: 2$ & 53 & 45 & 45 & 52 & \\
\hline \multirow{2}{*}{ Ductility at $25^{\circ} \mathrm{C}, \mathrm{cm}$} & $\mathrm{R}: \mathrm{O}=1: 1$ & 12 & 13.5 & 12.5 & 11.5 & \multirow{2}{*}{$\begin{array}{c}\text { According to standard } \\
11505\end{array}$} \\
\hline & $\mathrm{R}: \mathrm{O}=3: 2$ & 17 & 20 & 18 & 13 & \\
\hline \multirow{2}{*}{ Penetration index } & $\mathrm{R}: \mathrm{O}=1: 1$ & -0.5 & 1.8 & 0.6 & 2.3 & \multirow{2}{*}{ By empirical formula } \\
\hline & $\mathrm{R}: \mathrm{O}=3: 2$ & 1.0 & 0.9 & 1.8 & 1.5 & \\
\hline \multirow{2}{*}{$\begin{array}{c}\text { Changing of SP after } \\
\text { heated, }{ }^{\circ} \mathrm{C}\end{array}$} & $\mathrm{R}: \mathrm{O}=1: 1$ & 4 & 4 & 5 & 5 & \multirow{2}{*}{$\begin{array}{c}\text { According to standard } \\
18180\end{array}$} \\
\hline & $\mathrm{R}: \mathrm{O}=3: 2$ & 4 & 6 & 6 & 5 & \\
\hline \multirow{2}{*}{ Standard accordance } & $\mathrm{R}: \mathrm{O}=1: 1$ & - & RBC 60/90 & - & - & \multirow{2}{*}{$\begin{array}{l}\text { According to R RK } \\
218-76-2008\end{array}$} \\
\hline & $\mathrm{R}: \mathrm{O}=3: 2$ & $\mathrm{RBC} 60 / 90$ & RBC $130 / 200$ & $\mathrm{RBC} 130 / 200$ & - & \\
\hline
\end{tabular}

At experiment the spent engine oil was used as additional modifying agent. Standard accordance of rubber modified bitumen was determined according to "Recommendation on the application of crumb rubber in road construction R RK 218-76-2008". Physical and mechanical characteristics of rubber-bitumen compounds with activated rubber crumb and spent engine oil (rubber:engine oil $=1: 1$ and rubber:engine oil $=3: 2$ ) are given in table 2 .

As shown on table 2, physical and mechanical characteristics of $\mathrm{RBC}$ with 20 wt.\% rubber-oil (R:O=1:1) corresponds to grade of paving rubber-bitumen compounds RBC 90/130 and 25 wt.\% rubber-oil modified sample is according to standard RBC 130/200. The table showing physical and mechanical characteristics of RBC with $10 \mathrm{wt} . \%$ rubber-oil ( $\mathrm{R}: \mathrm{O}=3: 2)$ corresponds to grade of paving rubber-bitumen compounds RBC 60/90. Then RBC with 20 wt.\% rubber-oil added sample according to standard RBC $90 / 130$ and 25 wt.\% rubber-oil modified bitumen corresponds to grade of paving rubber-bitumen compounds RBC 130/200. Whereas the 15 wt.\% modified sample mismatch any standard of RBC.

\subsection{No Activated Rubber Crumb Modified Bitumen}

No activated rubber crumb modified bitumen was investigated same method and same experimental conditions with activated rubber-crumb modified samples. There are kindred phenomena, too: poor indicators, lower extensibility. Prepared samples were mismatch standard requirements of the rubber-bitumen compounds.

Physical and mechanical characteristics of rubber-bitumen compounds with no activated rubber crumb and spent engine oil (rubber:engine oil=1:1 and rubber:engine oil $=3: 2$ ) are given in table 3 . When we use no activated rubber crumb (06-1) in ratio $\mathrm{R}: \mathrm{O}=1: 1$ only one composition is a according to standard RBC 60/90. This is the 15 wt.\% rubber-oil modified sample, which is showing in table 3 .
As seen from the table that the sample of RBC added 10 wt. \% rubber-oil (R:O=1:1) mixtures are according to standard RBC 60/90, with 15 wt. \% and with 20 wt. \% rubber-oil modified bitumen correspond to grade of paving rubber-bitumen compounds RBC 130/200. Table 2 and table 3 showed, all the changing of softening temperature after heated results are according to standard requirements, which not more than 5 and $6{ }^{\circ} \mathrm{C}$. Penetration index are normal, too. Thus, all the tabulated results are allows knowing in ratio $3: 2$ rubber-oil mixture modified bitumen better than ratio of 1:1.

\subsection{Comparisons Characteristics of RBC}

The resulting rubber-bitumen compounds exhibit elasticity, increased softening point, decreased brittle point, and enhanced strength. These properties allow RBCs to be used both as binders for asphalt concretes and as mastics for pavement repair.

Physical and mechanical characteristics of prepared rubber-bitumen compounds were compared. Dependence of depth of needle penetration on the rubber-oil content of RBCs is showing in figure 4.

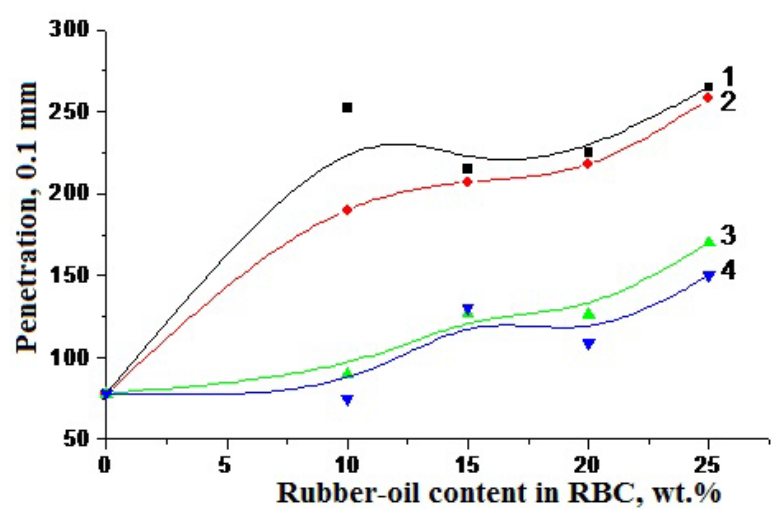

Figure 4. Dependence of penetration on the rubber-oil content of RBC, Rubber-oil ratio: 1 - 1:2, 2-2:3,3 - 1:1, 4-3:2 
Figure 4 presents, with increasing content of rubber-oil mixture from 5 wt. $\%$ to $25 \mathrm{wt} \%$ in bitumen, the penetration of rubber-bitumen compounds were increased. Otherwise softening point of RBC isn't more changing in any content of rubber-oil mixture. Dependence of ductility on the rubber-oil content of rubber-bitumen compounds is presenting at figure 5. It was shown that the ductility of RBC are decreasing depended to increase content of rubber-oil mixture in bitumen. This is due to the action of rubber particles as stress concentrators. It means the viscosity of bitumen compounds increased and starts to harden. These bitumen composition functions as a liquid or pseudo-thermoplastic matrix, the rubber particles provide resilient power frame in the amount of binder.

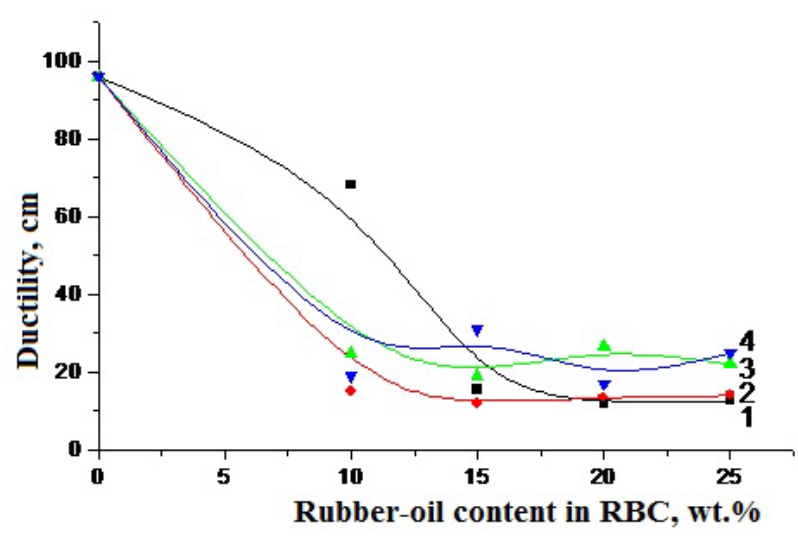

Figure 5. Dependence of ductility on the rubber-oil content of RBC, Rubber-oil ratio: $1-1: 2,2-2: 3,3-1: 1,4-3: 2$

The properties of crumb rubber modified bitumens, including the $\mathrm{RC}$ and crumb rubber with spent engine oil in ratio 1:1, are summarized in Table 4. By comparison, the properties of modified bitumen with the rubber-oil mixture are best, because of it is according to standard mark RBC 90/130. Its penetration and ductility are the highest, while softening point decrease. And RC modified bitumen due to poor extensibility $(7 \mathrm{~cm})$ were mismatch standard requirements of the rubber-bitumen compounds. It can be describe elasticity properties of engine oil for preparing modified bitumen on based rubber crumb.

Table 4. Properties Comparison of activated Crumb Rubber Modified Bitumens

\begin{tabular}{|l|c|c|c|}
\hline Kind of modifier & $\begin{array}{l}\text { Penetration, } \\
.1 \mathrm{~mm}\end{array}$ & $\begin{array}{l}\text { Softening } \\
\text { point, }{ }^{\circ} \mathrm{C}\end{array}$ & $\begin{array}{l}\text { Ductility, } \\
\mathrm{cm}\end{array}$ \\
\hline Base bitumen & 78 & 47 & 96 \\
\hline $\begin{array}{l}\text { Rubber crumb, } \\
10 \text { wt.\% }\end{array}$ & 52 & 57 & 7 \\
\hline $\begin{array}{l}\text { Rubber-oil mixture, } \\
20 \text { wt.\% }\end{array}$ & 126 & 50 & 26,5 \\
\hline
\end{tabular}

\section{Conclusion}

In the study physical and mechanical characteristics of rubber-bitumen compounds on based spent rubber items and spent engine oil were investigated experimentally. Scanning Electron Microscopy analyzes showed that crumb rubber has variety of morphological structures. It was determined, the RC is very low pores heterogeneous material. Standard accordance of rubber modified bitumen was determined according to "Recommendation on the application of crumb rubber in road construction R RK 218-76-2008". It is established that the quantity of entered binders depending on physical and chemical conditions, which was optimal composition of rubber-oil at a ratio of $1: 1$ and $3: 2$ and introduction to bitumen in amount of $15-25 \mathrm{wt} . \%$. On the physical and mechanical characteristics of rubber modified bitumen with engine oil ( $\mathrm{R}: \mathrm{O}=1: 1$ and $\mathrm{R}: \mathrm{O}=3: 2)$ correspond to grade of paving rubber-bitumen compounds RBC 60/90, $\mathrm{RBC} 90 / 130$ and $\mathrm{RBC} 130 / 200$. Adding of rubber crumb and modifier to bitumen were improved characteristics of prepared samples. At that time, rubber crumb and spent engine oil use to road construction will allow decrease environmental pollution with industrial wastes.

\section{REFERENCES}

[1] Songhun Yoon, Sharad Durgashanker Bhatt, Wonkyu Lee, Heung Yeoun Lee, Soon YongJeong, Jin-Ook Baeg, and Chul Wee Le. Separation and characterization of bitumen from Athabasca oil sand, Korean Journal of Chemical Engineering, Vol. 26, No. 1, 64-71, 2009.

[2] Mansurov Z.A., Ongarbaev E.K., Tuleutaev B.K., Utilization of Oil Wastes for Production of Road-building materials, Eurasian Chemico-Technological Journal, Vol. 2, No. 2, 161-166, 2000 .

[3] E.K. Ongarbaev, Z.A. Mansurov. Oil Wastes and Methods of utilization them, Kazakh University, Almaty, 2003.

[4] Asphalt and bitumen. Encyclopedia of chemistry (Ullmann's), Vol. 4, 273-294. DOI: 10.1002/14356007.a03_169.pub2

[5] D.G. Shunin, A.G. Filippova, N.A. Okhotina, A.G. Liakumovich, and Ya.D. Samuilov. Possibilities of Production and Use of Rubber-Bitumen Compounds, Russian Journal of Applied Chemistry, Vol. 75, No. 6, 1020-1023, 2002.

[6] Ongarbaev Ye., Doszhanov E.O., Mansurov Z.A. Processing heavy oil, oil residue and waste products, Kazakh University, Almaty, 2011.

[7] E.E. Gorlova, B.K. Nefedov, E.G. Gorlov, and A.A. Ol'gin. Reprocessing of Industrial Rubber Waste in a Mixture with Shale, Solid Fuel Chemistry, Vol. 42, No. 2, 93-94, 2008.

[8] Crumb rubber. Recycled pavement material, Online available from http://en.wikipedia.org

[9] E.E. Gorlova, B.K. Nefedov, and E.G. Gorlov. Manufacture of an Asphalt-Rubber Binder for Road Pavements by the Thermolysis of Tire Chips with Heavy Petroleum Residues, Solid Fuel Chemistry, Vol. 43, No. 4, 224-228, 2009.

[10] Mareike Hess, Harald Geisler, and Robert H. Schuster. 
Devulcanization as an opportunity to recycle rubber, Chem. Listy 103, s1-s148, PMA 2009 \& 20th SRC 2009, 58-60, 2009.

[11] L.A. Alamo-Nole, F. Roman and O. Perales-Perez. Sorption of Ethylbenzene, Toluene and Xylene onto Crumb Rubber from Aqueous Solutions, Online available from http://www.nsti.org

[12] Tyre and rubber recycling, Online available from http://www.dena.co.uk

[13] Artificialturf, Online available from http://www.ct.gov

[14] Waste Tire Disposal, Online available from http://www.state.tn.us

[15] Kyu-Dong Jeong, Soon-Jae Lee, Serji N. Amirkhanian, Kwang W. Kim. Interaction effects of crumb rubber modified asphalt binders, Construction and Building Materials, Vol. 24, 824-831, 2010.

[16] YE Zhi-gang, KONG Xiang ming, YU Jian-ying, WEI Lian-qi. Microstructure and Properties of Desulfurized Crumb Rubber Modified Bitumen, Journal of Wuhan University of Technology-Material Science Edition, Vol.18,
No.1, 83-85, 2003.

[17] Austruy F., Tileuberdi Ye., Ongarbaev Ye., Mansurov Z. Study of Production of Rubber-Bitumen Compounds, Eurasian Chemico-Technological Journal, Vol. 14, No. 2, 133-138, 2012.

[18] Tileuberdi Ye., Kozbakarova S., Ongarbaev Ye., Tuleutaev B., Mansurov Z. Use of rubber crumb for preparation asphalt-concrete, KazNU bulletin, chemical series, Vol. 65, № 1, 196-199, 2012.

[19] AO Ying, CAO Rongji. Interaction Theory of Asphalt and Rubber. Journal of Wuhan University of TechnologyMaterial Science Edition, Oct. 853-855, 2010.

[20] R.Z. Shakhnazarli, N. Ya. Ishchenko, Kh, G. Nazaraliev, B.A. Mamedov, A.M. Guliev. Polymer-Bitumen Compounds with Crumb Rubber, Secondary Polyethylene, and Polyamide Fiber Waste, Russian Journal of Applied Chemistry, Vol. 82, No. 7, 1310-1313, 2009.

[21] The complex modifier of asphalt concrete "KMA" koltech, Online available from http://koltech-stroy.ru

[22] UNIREM, Online available from http://ru.wikipedia.org 